\title{
The Effect of Storage on Some Properties of 3 Different Ground Poppy Seed Fats
}

\author{
Besim MADEN $^{* 1}$, Seda YALCIN ${ }^{1}$
}

${ }^{1}$ Afyon Vocational School, Food Technology Programme, Afyon Kocatepe University, Afyon, Turkey

Received: 03 May 2017 - Accepted: 08 July 2017

\begin{abstract}
The poppy seed is a traditional product in Afyon. There are there type poppy seed. These are white poppy seed, yellow poppy seed and gray poppy seed. The objective of this study is to investigate the effect of storage at $15-20^{\circ} \mathrm{C}$ for several times $(0,7,15,30,45$ and 60 days) on some properties of 3 different poppy seed fats. In this study, fats were obtained from white poppy seed (TMO1), yellow poppy seed (TMO2) and gray poppy seed (Afyon-95). Then free fatty acid amount (\%), peroxide value $\left(\right.$ meq $\left.\mathrm{O}_{2} / \mathrm{g}\right)$ and iodide number of these fats were analyzed. Free fatty acid amount, peroxide value and iodide number at these fats were increased with increasing of storage time, but this increase was little. The results of 3 different poppy seed fat were found as similar. It was concluded that three different poppy seed fats were stabile for long times at $15-20^{\circ} \mathrm{C}$. It was investigated the effects of storage on $\mathrm{L}^{*}, \mathrm{a}^{*}, \mathrm{~b}^{*}$ color values of three types of poppy seed fats and total phenolic contents of these fats were determined. The fat contents of three types of poppy seeds were found as $53.85 \%$ (white poppy seed), $49.85 \%$ (yellow poppy seed) and $49.17 \%$ (gray poppy seed). L* and $b^{*}$ color values of white poppy fat and gray poppy seed fat were decreased when storage time was increased, while $a^{*}$ color values of those were increased. $\mathrm{L}^{*}$ and $\mathrm{a}^{*}$ color values of yellow poppy seed fats were increased when storage time was increased, whereas $b^{*}$ color value of that was decreased.
\end{abstract}

Keywords: Fat, Phenolic, Poppy seed, Storage, Stability

\section{INTRODUCTION}

Poppy (papaver somniferum) is cultivated as an annual crop in China, India and Turkey. Poppy seeds had palmitic acid, stearic acid, oleic acid, linoleic acid and linolenic acid. Linoleic acid was found at high level in poppy seeds [1]. Ozcan and Atalay, 2006 [1] reported that phosphorus and potassium are high in poppy seed. Fat content of poppy seed was in the range of $45-50 \%$. Poppy fat has approximately $73 \%$ linoleic acid, $10 \%$ palmitic acid and $17 \%$ oleic acid [2]. Bozan and Temelli, 2008 [3] investigated fatty acids, tocopherols, tocotrienols and safflower oils. It was reported that poppy oil was rich in linoleic acid, which was compresing of $74.5 \%$ total fatty acids. The poppy fat contained mainly gamma-tocopherols $(30.9 \mathrm{mg} / 100 \mathrm{~g})$. Oxidative stability of poppy fat was $5.56 \mathrm{~h}$ at $110^{\circ} \mathrm{C}$ and $20 \mathrm{~L} / \mathrm{h}$ air flow rate [3]. Inan et all. 2012 [4] investigated the antioxidant effect of mint, laurel and myrtle leaf essential oils on pomegranate kernel, poppy, grape and linseed oils which were stored at $60^{\circ} \mathrm{C}$ for 6 weeks. It was reported that essential oils improved oxidative stability of the edible oils. The peroxide

*Corresponding Author E-mail: besimmaden@aku.edu.tr 
values of poppy oil on 6th week were lower for samples with mint and myrtle essential oils addition (0.05\%) than those with laurel leaf essential oil [4]. Ozcan and Arslan 2011 [5] investigated the antioxidant effect of essential oils of rosemary, clove and cinnamon on hazelnut and poppy oils. The antioxidant activity of the essential oils was determined by measuring peroxide values at regular intervals at $50^{\circ} \mathrm{C}$ for 14 days in darkness. It was reported that essential oils gave strong antioxidant effect to hazelnut oil and poppy oil, especially cinnamon oil. Antioxidant effect increased with concentration of essential oil. This effect was more remarkable for poppy oil [5].

The objective of this study is to determine the effects of storage time on oxidation properties, iodide number and color values of white poppy seed fat, yellow poppy seed fat and gray poppy seed fat.

\section{MATERIALS AND METHODS}

White poppy seed (TMO-1), yellow poppy seed (TMO-2) and gray poppy seed (Afyon95) were supplied from Afyon Toprak Mahsulleri Ofisi (Turkey). These poppy seeds were ground and obtained fats of them.

\subsection{Analysis of 3 different poppy seeds}

The fat contents of white poppy seed, yellow poppy seed and gray seed were determined by soxhlet instrument (S\&H Labware, China).

\subsection{Analysis of 3 different poppy seed fats}

Poppy seed fats were stored at $15-20^{\circ} \mathrm{C}$ for $0,15,30,45$ and 60 days. These samples were analyzed for peroxide value, free fatty acid value and iodide number value according to the method of [6.7.8]. Color values $\left(\mathrm{L}^{*}, \mathrm{a}^{*}, \mathrm{~b}^{*}\right)$ of different poppy seed fats were determined by using X-rite instrument (USA). $\mathrm{L}^{*}$ color value gives lightness, $\mathrm{a}^{*}$ color value gives redness and $b^{*}$ color values gives yellowness.

\section{RESULTS and DISCUSSIONS}

\subsection{Analysis of 3 different poppy seeds}

The fat amounts of white poppy seed, yellow poppy seed and gray poppy seed were found as $53.9 \%, 49.9 \%$ and $49.2 \%$, respectively. White poppy seed had higher fat content than the other poppy seeds. Photographs of 3 different poppy seeds were given in Fig.1.
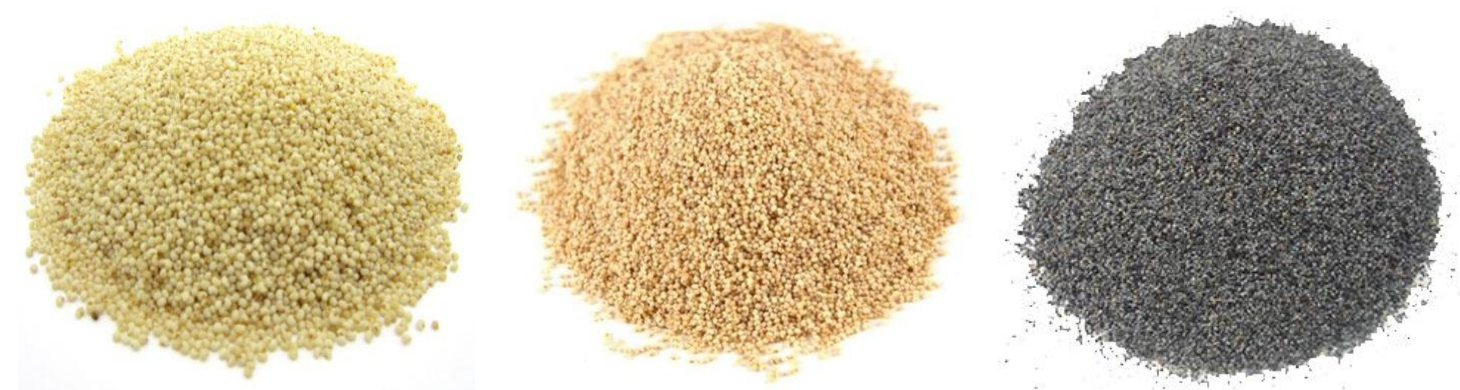

Figure 1. Photographs of white, yellow and gray poppy seeds

\subsection{Analysis of 3 different poppy seed fats}

\subsubsection{Peroxide values of fats}

Effect of storage at $15-20^{\circ} \mathrm{C}$ for several times $(0,7,15,30,45$ and 60 days) on peroxide values of 3 different fats was given in Fig. 2. Peroxide and values of white poppy seed fat, 
yellow poppy seed fat and gray poppy seed fat were increased with increasing of storage time. The increase in peroxide value of white poppy seed fat was higher (15.9\%) than yellow poppy seed fat $(11.4 \%)$ and gray poppy seed fat $(9.1 \%)$.

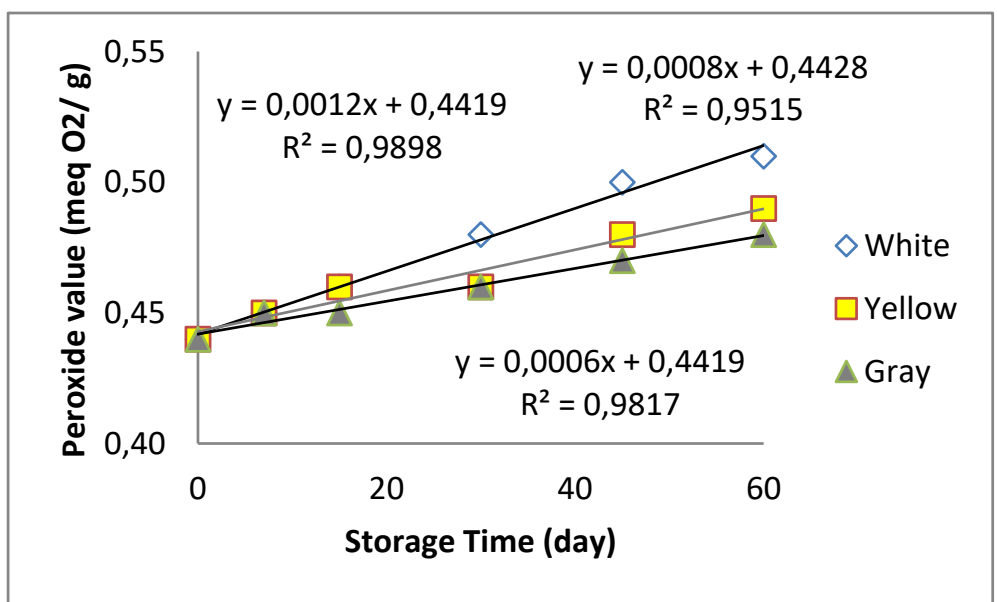

Figure 2. Effect of storage time on peroxide values of 3 different poppy seed fats

\subsubsection{Free fatty acid amount of fats}

Effect of storage at $15-20^{\circ} \mathrm{C}$ for several times $(0,7,15,30,45$ and 60 days) on free fatty acid amounts of 3 different fats was given in Fig. 3 free fatty acid amounts of white poppy seed fat, yellow poppy seed fat and gray poppy seed fat were increased, when storage time was increased from 0 day to 60 days. The increases in free fatty acid amounts of white poppy seed fat $(10.0 \%)$, yellow poppy seed fat $(6.7 \%)$ and gray poppy seed fat $(8.3 \%)$ were nearly similar.

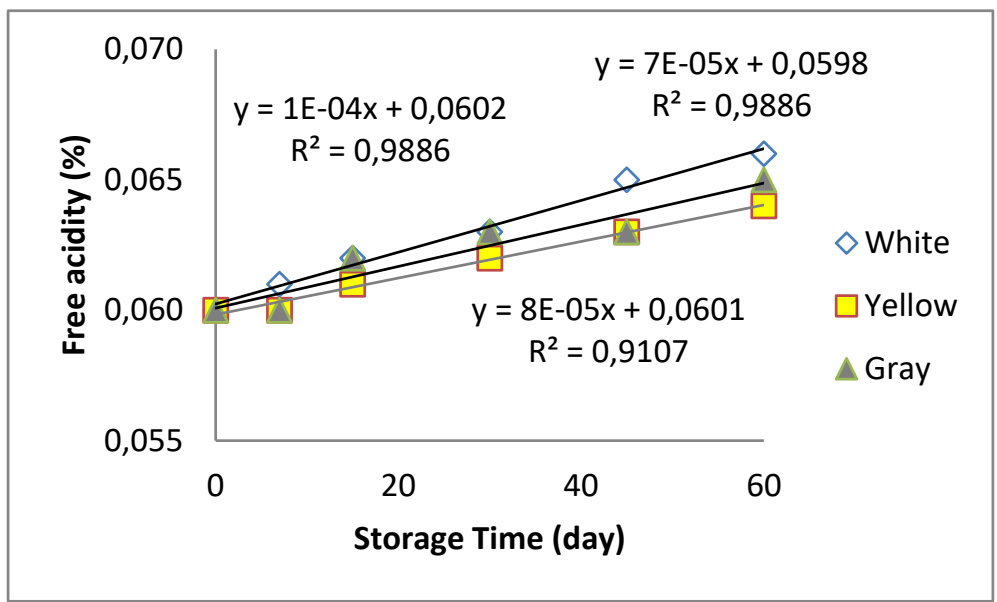

Figure 3. Effect of storage time on free fatty acid values of 3 different poppy seed fats

\subsubsection{Iodide number of fats}

Effects of storage at $15-20^{\circ} \mathrm{C}$ for several times $(0,7,15,30,45$ and 60 days) on iodide number of 3 different fats was given in Fig. 4. The change in iodide numbers of white poppy seed fat, yellow poppy seed fat and gray poppy seed fat with storage time was little. 


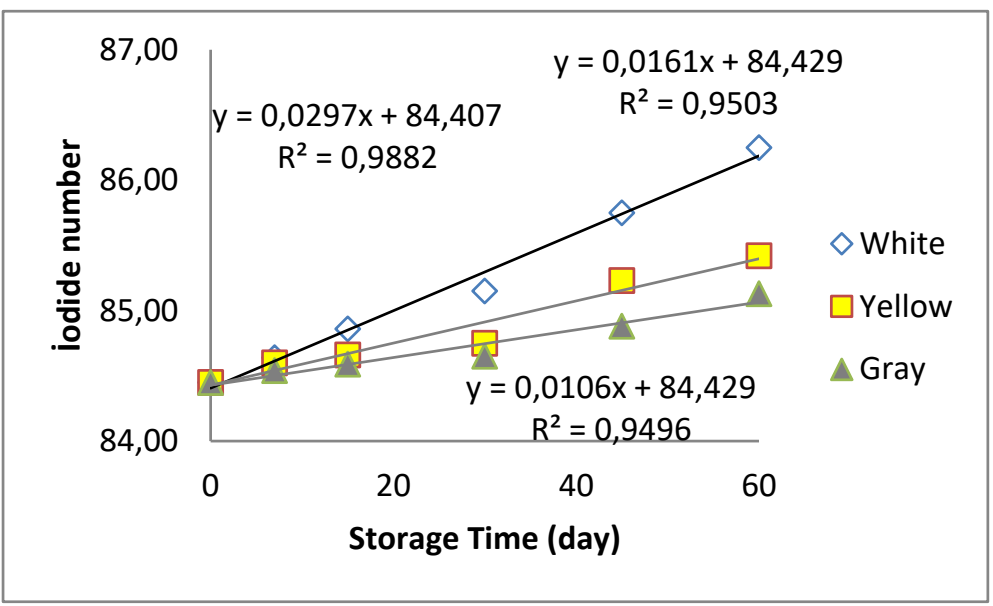

Figure 4. Effect of storage time on iodide number values of 3 different poppy seed fats

\subsubsection{Color values of fats}

$\mathrm{L}^{*}, \mathrm{a}^{*}$ and $\mathrm{b}^{*}$ color values of 3 different fats and these values after storage of 3 different fats at $15-20^{\circ} \mathrm{C}$ for 30 days and 60 days were given in Fig. 5.6.7. $\mathrm{L}^{*}$ color values of white poppy seed fat and gray poppy seed fat were decreased with increasing of storage time, while that of yellow poppy seed fat was increased. $a^{*}$ color values of white poppy seed fat, yellow poppy seed fat and gray poppy seed fat were increased when storage time was increased. $b^{*}$ color value of white poppy seed fat was decreased with storage time.

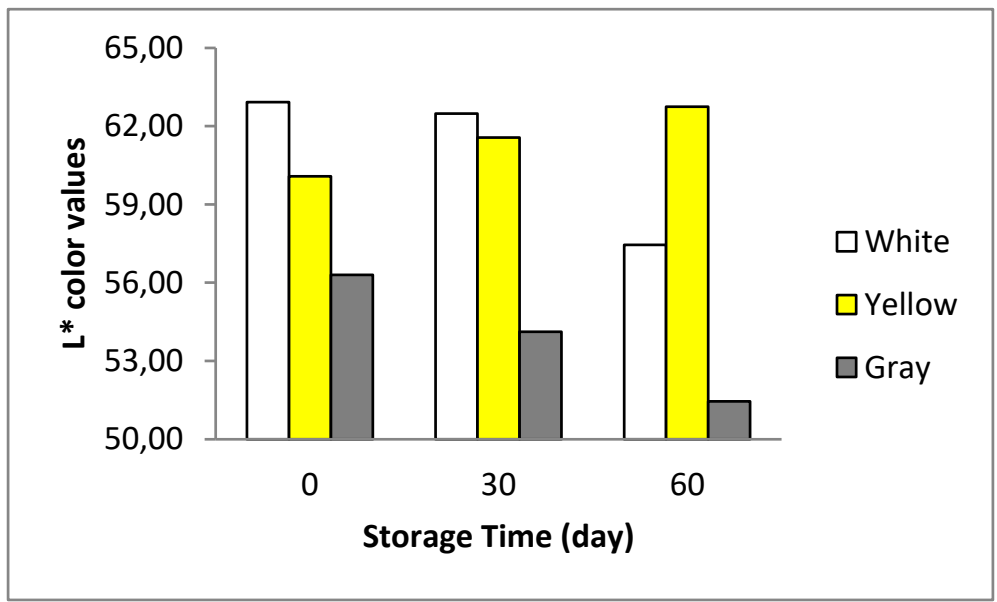

Figure 5. Effect of storage time on $\mathrm{L}^{*}$ color values of 3 different poppy seed fats

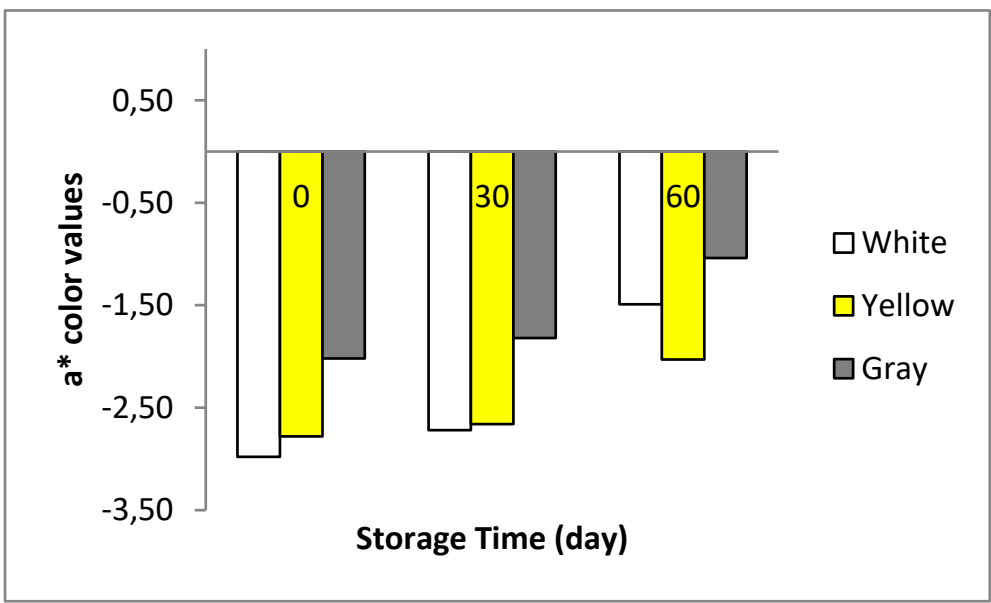

Figure 6. Effect of storage time on $a^{*}$ color values of 3 different poppy seed fats 


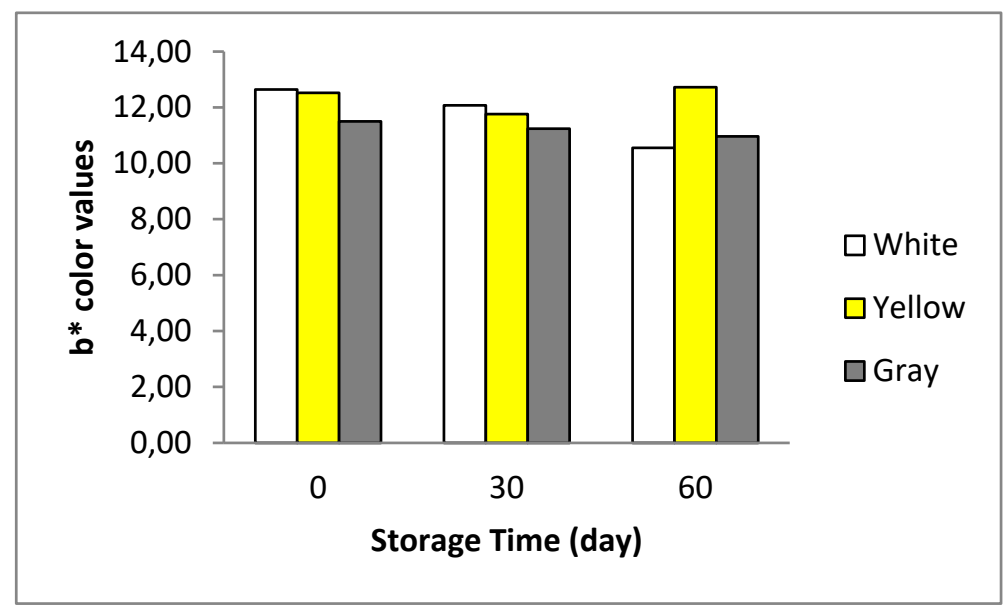

Figure 7. Effect of storage time on $b^{*}$ color values of 3 different poppy seed fats

\section{CONCLUSION}

In this study, the effect of storage time on peroxide value, free fatty acidity, iodide number and color $\left(\mathrm{L}^{*}, \mathrm{a}^{*}, \mathrm{~b}^{*}\right)$ properties of fats obtained from 3 different poppy seeds (white poppy seed, yellow poppy seed, gray poppy seed) which were grown in Afyon was determined. It was found that correlations $\left(\mathrm{R}^{2}\right)$ between peroxide value, free fatty acidity, iodide number of 3 different poppy seed fats with storage time (from 0 to 60 days) were $0.9898,0.9886,0.9882$ (white poppy seed fat), 0.9515, 0.9886, 0.9503 (yellow poppy seed fat) and 0.9817, 0.9107, 0.9496 (gray poppy seed fat), respectively. There was also change in $\mathrm{L}^{*}, \mathrm{a}^{*}$ and $\mathrm{b}^{*}$ color value of 3 different poppy seed fats with storage time. The change in these values was not high.

\section{Acknowledgement}

We wish to thank Afyon Toprak Mahsulleri Ofisi (Turkey) for providing of 3 different poppy seeds.

\section{Conflict of Interests}

Authors declare that there is no conflict of interests.

\section{REFERENCES}

[1] Ozcan, M. M., \& Atalay, C. (2006). Determination of seed and oil properties of some poppy (Papaver somniferum L.) varieties. Grasas Y Aceites, 57(2), 169-174.

[2] Nergiz, C., \& Ötles, S. (1994). The proximate composition and some minor constituents of poppy seeds. Journal of the Science of Food and Agriculture, 66, 117-120.

[3] Bozan, B., \& Temelli F. (2008). Chemical composition and oxidative stability of flax, safflower and poppy seed and seed oils. Bioresource Technology, 99, 6354-6359.

[4] Inan, Ö, Özcan, M.M., \& Al Juhaimi, F.Y. (2012). Antioxidant effect of mint, laurel and myrtle leaves essential oils on pomegranate kernel, poppy, grape and linseed oils. J Clean Prod. 27, 151-154.

[5] Ozcan, M. M., \& Arslan, D. (2011). Antioxidant effect of essential oils of rosemary, clove and cinnamon on hazelnut and poppy oils. Food Chemistry, 129, 171-174. DOI:10.1016/j.foodchem.2011.01.055

[6] Official Methods and Recommended Practices of the American Oil Chemists' Society. 3rd edn., American Oil Chemists' Society, Champaign, 1993. Iodine Value of Fats and Oils, Wijs Method. Official Method Cd 1-25, Corrected 1991.

[7] Official Methods and Recommended Practices of the American Oil Chemists' Society, 3rd edn., American Oil Chemists' Society, Champaign, 1993. Iodine Value of Fats and Oils, Cyclohexane Method. Official Recommended Practice Cd 1b-87, Revised 1990. 
[8] Official Methods and Recommended Practices of the American Oil Chemists' Society, 3rd edn., American Oil Chemists' Society, Champaign, 1993. Iodine Value of Fats and Oils, Cyclohexane-Acetic Acid Method. Official Recommended Practice Cd 1d-92. 